\title{
Nitrogen utilization by male WAD sheep fed graded levels of boiled CST and SMD based diets
}

Ettu $^{1}$, R. O and Onwuka 2 , C. F. I.

${ }^{1}$ Agricultural Science Department, Tai Solarin University of Education, Ijebu Ode, Nigeria. ${ }^{2}$ College of Animal Science and Livestock Production, Federal University of

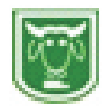

Agriculture, Abeokuta, Nigeria.

tunjiettu@gmail.com

\begin{abstract}
The study was carried out to investigate the nitrogen utilization by male West African Dwarf (WAD) sheep fed boiled Cocoa Seed Testa (CST) and Sorghum Malt Dust (SMD)-based diets. Twenty-eight male animals were divided into seven groups with similar average initial live weight in a completely randomized design. Each group contained four animals. The trial consisted of seven dietary treatments which comprised CST at 10,20 and 30\% levels, SMD at 10, 20 and 30\% levels and a control. The trial lasted for 90 days. Data generated were subjected to a one-way analysis of variance. Apparent nitrogen intake $(19.41 \mathrm{~g} / \mathrm{d})$ and retention $(9.67 \mathrm{~g} / \mathrm{d})$ were significantly $(P<0.05)$ higher in the treatment with $20 \%$ SMD. Generally, dietary inclusion of CST and SMD improved the nitrogen intake by male WAD sheep with the best result from sheep fed $20 \%$ sorghum malt dust based diets.
\end{abstract}

Keywords : WAD sheep, nitrogen intake, diets, cocoa seed testa, sorghum malt dust

\section{Introduction}

The ultimate objective of the livestock industry is the conversion into animal products of food which is either inedible by man or is surplus for his immediate requirements. Forages with low crude protein cannot sustain live weight in animals and this necessitates supplementation with proteinous feedstuffs. Adegbola (1985) noted that ruminants could not meet their maintenance need on grass alone. The requirement for any nutrient is the amount of that nutrient which must be supplied in the ration to meet the needs of the animals. Such level of nutrient must be capable of meeting the requirement for maintenance of the animals (Awujoola, 1999). In sheep rations, the amount of protein is much more important than quality of protein since mature sheep like any other ruminant, use the naturally occurring protein and non-protein nitrogen (Urea) in their diets effectively (Clay,
2000). Aganga (1988) reported that the extent of protein degradation depends largely on the solubility of the feed, the physical form and the level of intake. Nitrogen is utilized by the ruminants for maintaining body tissues and also for growth processes and production. Ummuna et al. (1982) found that lambs fed soyabean meal (SBM) supplemented ration retained more nitrogen and those supplemented with urea alone had lower nitrogen retention than those supplemented with Corn Gluten Meal (CGM) alone or the CGM -urea combinations.

The present study investigated nitrogen utilization by WAD sheep fed graded levels of boiled CST and SMD based diets which are two readily available crop by-products.

\section{Materials and Methods}

Twenty-eight (28) West African Dwarf male sheep were used for the study. The sheep (aged 11-13 months) were sourced 
from villages around Ijebu-Ode. The average live weight ranged between 10.08 and $10.66 \mathrm{~kg}$. The animals were dewormed with Levamisole ${ }^{\circledR}$ and dipped in diasuntol ${ }^{\circledR}$ solution to get rid of ectoparasites. The sheep were housed in disinfected and well ventilated pens. They were given feed (Gliricidia sepium and concentrate supplement) with free access to water for fourteen (14) days prior to the beginning of experiments in order to ensure uniform preexperimental management.

Experimental Diets Preparation

Experimental diets used were made up of Cocoa Seed Testa (CST) and Sorghum Malt Dust (SMD) based diets as supplement to Gliricidia sepium. CST and SMD were boiled at $100^{\circ} \mathrm{C}$ for 60 minutes to reduce the effects of anti-nutritional factors therein. Seven experimental concentrate diets were prepared using the cocoa seed testa and sorghum malt dust at 10, 20 and 30\% respectively as shown in Table 1 . The Gliricidia sepium leaves and branches were cut, chopped and sun dried for two and half hours to three hours to reduce moisture content before they were supplied to experimental animals. Twenty-eight male animals were divided into seven groups with similar average initial live weight in a completely randomized design. Each group contained four male animals. Animals were fed at $5 \%$ of their body weights in a trial that lasted for 90 days. The concentrate supplements were given to the animals in the morning while Gliricidia sepium was given to the animals in the evening.

Ten weeks into the feeding trials, two animals from each group were randomly selected and transferred into the metabolic cages modified for the collection of faeces and urine. The first 14 days were used to acclimatize the animals while the last seven days were used for the collection of faeces and urine for analysis. The total daily faecal output for each animal was weighed before $10 \%$ of the sample was removed. The wet samples were dried at $65^{\circ} \mathrm{C}$ to constant weight and bulked for each animal for subsequent analysis. The urine samples were collected in container with $5 \%$ diluted $\mathrm{H}_{2} \mathrm{SO}_{4}$ to prevent volatilization and refrigerated till needed for analysis.

The results of nitrogen intake, excretion (faecal and urinary) and nitrogen balance were computed and subjected to a one-way analysis of variance using SPSS (1999). Differences between treatment means were separated using Duncan's Multiple Range Test of the same statistical package.

\section{Results and Discussion}

Highest nitrogen intake value was obtained in diet $5(19.41 \mathrm{~g} / \mathrm{d})$ but was not significantly $(\mathrm{P}>0.05)$ different from all other diets except diet 7 (control diet) where the lowest nitrogen intake was observed $(15.93 \mathrm{~g} / \mathrm{d})$. Nitrogen excretion in faeces and urine increased with increasing concentration of CST but decreased as the level of inclusion of SMD increased in the diets for faecal nitrogen. Also, there was an increase in the value obtained for urinary nitrogen and also a decrease in value obtained in control diet. Despite the decrease in the values obtained for faecal nitrogen in diets 4, 5 and 6 there was no significant $(\mathrm{P}>0.05)$ difference in the value obtained as experienced in diets 1,2 and 3 where we have the inclusion of CST.

The total nitrogen excreted ranged from 8.10 to $10.65 \mathrm{~g} / \mathrm{d}$. There was a significant difference $(\mathrm{P}<0.05)$ in the nitrogen excreted among the treatments except diets 4, 5 and 7 but there was only numerical differences in diets 2, 4, 5 and 6 . Nitrogen balance was lowest $(5.28 \mathrm{~g} / \mathrm{d})$ in the control while the highest value was obtained in diet 5 $(9.67 \mathrm{~g} / \mathrm{d})$. The nitrogen balance values were not really significantly $(\mathrm{P}>0.05)$ 
Table 1: Composition of experimental diets fed to West African Dwarf sheep (\%)

\begin{tabular}{|c|c|c|c|c|c|c|c|}
\hline \multirow[b]{2}{*}{ Ingredients } & \multicolumn{7}{|c|}{ Diets } \\
\hline & 1 & 2 & 3 & 4 & 5 & 6 & 7 \\
\hline $\begin{array}{l}\text { Cassava Root Meal } \\
\text { Boiled Cocoa Seed }\end{array}$ & 58 & 48 & 38 & 58 & 48 & 38 & 68 \\
\hline $\begin{array}{l}\text { Testa } \\
\text { Boiled Sorghum Malt }\end{array}$ & 10 & 20 & 30 & 0 & 0 & 0 & 0 \\
\hline Dust & 0 & 0 & 0 & 10 & 20 & 30 & 0 \\
\hline Wheat Offal & 30 & 30 & 30 & 30 & 30 & 30 & 30 \\
\hline Premix* & 1 & 1 & 1 & 1 & 1 & 1 & 1 \\
\hline Salt & 1 & 1 & 1 & 1 & 1 & 1 & 1 \\
\hline TOTAL & 100 & 100 & 100 & 100 & 100 & 100 & 100 \\
\hline
\end{tabular}

Table 2: Determined analysis of experimental diets (\%)

\begin{tabular}{lccccccc}
\hline & 1 & 2 & 3 & 4 & 5 & 6 & 7 \\
\hline Dry matter & 89.59 & 89.48 & 89.66 & 89.91 & 89.78 & 89.55 & 89.63 \\
Crude protein & 15.18 & 14.37 & 14.28 & 14.57 & 14.89 & 14.76 & 12.06 \\
Crude fibre & 15.38 & 15.41 & 15.58 & 14.71 & 14.93 & 14.99 & 15.16 \\
$\begin{array}{l}\text { Diet 1 = 10\% inclusion of CST, Diet 2 }=20 \% \text { inclusion of CST, Diet 3 = 30\% inclusion of CST, Diet 4 = 10\% inclusion of } \\
\text { SMD, Diet 5 = 20\% inclusion of SMD, Diet 6 = 30\% inclusion of SMD, Diet 7 = 0\% inclusion of SMD and CST }\end{array}$
\end{tabular}

Table 3: Chemical Composition of the Test Ingredients (g/100gDM)

\begin{tabular}{llllll}
\hline Parameters & $\begin{array}{l}\text { Unboiled } \\
\text { CST }\end{array}$ & $\begin{array}{l}\text { Boiled } \\
\text { CST }\end{array}$ & $\begin{array}{l}\text { Unboiled } \\
\text { SMD }\end{array}$ & $\begin{array}{l}\text { Boiled } \\
\text { SMD }\end{array}$ & $\begin{array}{l}\text { Gliricidiase } \\
\text { pium }\end{array}$ \\
\hline Dry matter & 89.67 & 87.96 & 89.36 & 88.06 & 30.12 \\
Crude protein & 18.67 & 11.48 & 15.68 & 12.97 & 19.30 \\
Crude fibre & 21.29 & 19.37 & 13.23 & 12.17 & 12.80 \\
Ash & 8.75 & 6.28 & 5.74 & 4.38 & 10.12 \\
Ether extract & 0.85 & 0.81 & 3.27 & 2.96 & 2.16 \\
$\begin{array}{l}\text { Nitrogen free } \\
\text { extract }\end{array}$ & 40.11 & 50.02 & 51.44 & 55.58 & 55.62 \\
$\begin{array}{l}\text { Gross energy } \\
\text { (Kcal/g) }\end{array}$ & 2.97 & 2.87 & 2.97 & 2.93 & 4.61 \\
\hline *Average of 2 replicates & & & &
\end{tabular}


Table 4: Chemical composition of boiled Cocoa Seed Testa and Sorghum Malt Dust based-diets (g/100gDM)

\begin{tabular}{|c|c|c|c|c|c|c|c|}
\hline \multirow[t]{2}{*}{ Parameters } & \multicolumn{7}{|l|}{ Diets } \\
\hline & 1 & 2 & 3 & 4 & 5 & 6 & 7 \\
\hline Dry matter & 89.59 & 89.48 & 89.66 & 89.71 & 89.78 & 89.55 & 89.63 \\
\hline Crude protein & 15.18 & 14.37 & 14.28 & 14.57 & 14.89 & 14.76 & 12.06 \\
\hline Crude fibre & 15.38 & 15.41 & 15.58 & 14.71 & 14.92 & 14.99 & 15.16 \\
\hline Ether extract & 2.55 & 2.59 & 2.64 & 2.66 & 2.58 & 2.61 & 2.53 \\
\hline Ash & 11.16 & 10.68 & 10.76 & 10.96 & 10.91 & 10.46 & 11.13 \\
\hline $\begin{array}{l}\text { Nitrogen Free } \\
\text { Extract }\end{array}$ & \multicolumn{6}{|c|}{ Extract } & 48.75 \\
\hline NDF & 1.51 & 1.46 & 1.42 & 1.38 & 1.32 & 1.34 & 1.41 \\
\hline $\mathrm{ADF}$ & 1.46 & 1.37 & 1.33 & 1.26 & 1.29 & 1.28 & 1.38 \\
\hline ADL & 0.18 & 0.17 & 1.01 & 0.08 & 0.06 & 0.11 & 0.13 \\
\hline \multicolumn{8}{|c|}{$\begin{array}{l}\text { Diet } 1=10 \% \text { inclusion of CST, Diet } 2=20 \% \text { inclusion of CST, Diet } 3=30 \% \text { inclusion of CST, Diet } 4=10 \% \text { inclusion } \\
\text { of SMD, Diet } 5=20 \% \text { inclusion of SMD, Diet } 6=30 \% \text { inclusion of SMD, Diet } 7=0 \% \text { inclusion of SMD and CST }\end{array}$} \\
\hline \multicolumn{4}{|c|}{$\begin{array}{l}\text { affected by the dietary treatments except for } \\
\text { treatments } 3 \text { ( } 30 \% \text { inclusion of CST) and } 7 \\
\text { (control). } \\
\text { The N-intakes recorded in this study were } \\
\text { higher than } 13.85 \pm 0.58 \text { obtained for sheep } \\
\text { fed Panicum maximum and also } 10.05 \pm \\
0.02 \text { obtained for sheep fed Vetiveria } \\
\text { nigeritana by Aderinola et al (2008). } \\
\text { Higher nitrogen intake in the study was as a } \\
\text { result of Gliricidia sepium used as basal } \\
\text { feed because supplementation of ruminant } \\
\text { feed with leguminous tree is a way of }\end{array}$} & \multicolumn{4}{|c|}{$\begin{array}{l}\text { alleviating nitrogen deficiencies (Mc } \\
\text { Sweeney etal., 1999). } \\
\text { Nitrogen balance and retention values were } \\
\text { higher in all the diets and this shows the } \\
\text { potentiality of CST and SMD in } \\
\text { conjunction with other feed ingredients to } \\
\text { enhance N utilization. Values obtained in } \\
\text { this study were lower than previously } \\
\text { reported values in sheep fed shrimp waste } \\
\text { meal and soya bean stover based diets } \\
\text { (Oduguwa et al., 2007) but higher than } \\
\text { those fed Panicum maximum as well as }\end{array}$} \\
\hline
\end{tabular}

Table 5: Nitrogen utilization by WAD sheep fed graded levels of boiled CST and SMD-based diets

\begin{tabular}{|c|c|c|c|c|c|c|c|c|}
\hline \multirow[t]{2}{*}{ Parameters } & \multicolumn{7}{|c|}{ Diets } & \multirow[b]{2}{*}{ SEM } \\
\hline & 1 & 2 & 3 & 4 & 5 & 6 & 7 & \\
\hline Nitrogen intake $(\mathrm{g} / \mathrm{d})$ & $17.70^{\mathrm{ab}}$ & $18.28^{\mathrm{a}}$ & $17.47^{\mathrm{ab}}$ & $18.68^{\mathrm{a}}$ & $19.41^{\mathrm{a}}$ & $18.26^{\mathrm{a}}$ & $15.93^{b}$ & 2.10 \\
\hline $\begin{array}{l}\text { Nitrogen excretion } \\
(\mathrm{g} / \mathrm{d})\end{array}$ & & & & & & & & \\
\hline Faecal & $6.49^{\mathrm{b}}$ & $7.28^{\mathrm{b}}$ & $8.87^{\mathrm{a}}$ & $7.94^{\mathrm{ab}}$ & $7.93^{\mathrm{ab}}$ & $7.23^{\mathrm{b}}$ & $8.92^{\mathrm{a}}$ & 1.01 \\
\hline Urinary & $1.61^{b}$ & $1.64^{\mathrm{b}}$ & $1.73^{\mathrm{a}}$ & $1.79^{\mathrm{a}}$ & $1.81^{\mathrm{a}}$ & $1.76^{\mathrm{a}}$ & $1.73^{\mathrm{a}}$ & 0.08 \\
\hline Total & $8.10^{\mathrm{b}}$ & $8.92^{b}$ & $10.60^{\mathrm{a}}$ & $9.73^{\mathrm{ab}}$ & $9.74^{\mathrm{ab}}$ & $8.99^{\mathrm{b}}$ & $10.65^{\mathrm{a}}$ & 1.58 \\
\hline Nitrogen balance & $9.60^{\mathrm{a}}$ & $9.36^{\mathrm{a}}$ & $6.87^{\mathrm{b}}$ & $8.95^{\mathrm{a}}$ & $9.67^{\mathrm{a}}$ & $9.27^{\mathrm{a}}$ & $5.28^{\mathrm{c}}$ & 0.92 \\
\hline $\begin{array}{l}\text { Nitrogen balance } \\
\left(\mathrm{g} / \mathrm{dW}^{0.75}\right)\end{array}$ & $5.45^{\mathrm{a}}$ & $5.35^{\mathrm{a}}$ & $4.24^{\mathrm{bc}}$ & $5.17^{\mathrm{ab}}$ & $5.48^{\mathrm{a}}$ & $5.31^{\mathrm{ab}}$ & $3.48^{\mathrm{c}}$ & 1.08 \\
\hline Nitrogen balance $(\%)$ & $54.23^{\mathrm{a}}$ & $51.20^{\mathrm{a}}$ & $39.32^{b}$ & $47.91^{\mathrm{a}}$ & $49.81^{\mathrm{a}}$ & $50.76^{\mathrm{a}}$ & $33.14^{\mathrm{b}}$ & 6.35 \\
\hline
\end{tabular}


Vetiveria nigeritana (Aderionla et al., 2008). The levels of nitrogen retention may be as a result of the digestibility of nutrients in all the diets containing CST and SMD.

The result of the study shows that the experimental animals had the best nitrogen utilization on $20 \%$ sorghum malt dust based diets.

\section{Conclusion}

The levels of nitrogen retention may be as a result of the digestibility of nutrients in all the diets containing CST and SMD. Available nitrogen in the experimental diets was better utilized by the animals that consumed boiled Sorghum Malt Dust than those that consumed boiled Cocoa Seed Testa.

\section{References}

Adegbola, T. A. 1985. Browse plants: Propagation, Management and Utilization. Proceeding National Conference on Small Ruminant Prod., Zaria .Pg. 85-89

Aderinola O. A., Akinlade, J. A., Rafiu T. A., and Fajinmi T. 2008. Feed intake, Digestibility and Nitrogen balance of West African Dwarf Sheep and Goats fed Vetveria nigritana Grass. Proceedings of $33^{\text {rd }}$ Annual Conference of Nigeria Society for Animal Production, Ayetoro, Ogun State, 2008. Pg. $579-$ 582

Aganga, A. A. 1988. Influence of Intermittent Watering on Some Blood Components of Grazing
Yankasa Sheep. Nig. J. Anim. Prod.15: 77-82

Awujoola, O. M. 1999. Sheep and Goat Nutrient Requirements. Heinemann Education Books (Nig) Plc. Ibadan

Clay, P. M. 2000. Sheep Production and Management New Mexico State University.

McSweeney, C. S., Palmer, B., Bunch, R. and Krause, D. O. 1999. In vitro quality assessment of tannin containing tropical shrub legumes: Protein and fibre digestion. Anim. Feed Sci. Tech. 82: 227-241.

Oduguwa, B. O., Jolaosho, A. O., Arigbede, O. M, and Adu, I. F. 2007. Performance of West African dwarf sheep fed graded levels of shrimp waste meal (SWM) and soyabean stover based diets. Proceedings of $32 \mathrm{nd}$ Annual Conference of Nigeria Society for Animal Production, Calabar, 2007.Pp538-540.

SPSS, 1999. Statistical Package for Social Sciences. Procedures and facilities for release. 6.0 Users' Manual, McGraw-Hll Book Co. NY.

Ummuna, N. N., Klopfenstein, T. J. Hesmoglu, S and Woods, W. R. 1982. Evaluation of Corn Gluten meal with Urea as a source of Supplementary Nitrogen for Growing Calves and Lambs. Anim. Feed Sci. Tech. 7: 375-381.

Received: 22 $2^{\text {nd }}$ January, 2014 Accepted: $17^{\text {th }}$ February, 2015 